Robert B. Forbes MD FrCPC, David J. Muray MD, Judith B. Dillman MD, David L. Dull MD

\title{
Pharmacokinetics of two per cent rectal methohexitone in children
}

Plasma methohexitone concentrations were determined in 60 children, aged one to six years, following administration of $15 \mathrm{mg} \cdot \mathrm{kg}^{-1}, 20 \mathrm{mg} \cdot \mathrm{kg}^{-1}, 25 \mathrm{mg} \cdot \mathrm{kg}^{-1}$ or $30 \mathrm{mg} \cdot \mathrm{kg}^{-1}$ twopercent rectal methohexitone. Time to the onset of sleep was determined by a blinded observer and venous blood samples obtained 15 , 30,45 and 120 minutes following drug administration. Fify of 60 children were asleep within 15 minutes. Nine of the ten children that did not fall asleep were sedate and could be separated easily from their parents to undergo inhalational induction of anaesthesia. Time to the onset of sleep was inversely related to the dose of rectal methohexitone administered. Sleep was achieved more reliably following the use of 2.5 to $30 \mathrm{mg} \cdot \mathrm{kg}^{-1}$ rectal methohexitone. In addition, plasma methohexitone concentrations following $30 \mathrm{mg} \cdot \mathrm{kg}^{-1}$ rectal methohexitone were significantly higher for up to 120 minutes following drug administration than the plasma concentration. achieved after $15 \mathrm{mg} \cdot \mathrm{kg}^{-1}$ or $20 \mathrm{mg} \cdot \mathrm{kg}^{-1}$ methohexitone. There was no difference in the incidence of complications. The authors recommend that clinical circunstances be carefully considered and the dose of rectal methohexitone administered be individualized to meet the specific anaesthetic requirements of each child.

\section{Key words}

ANAESTHESIA: pQEdiatric; ANAESTHETICS, RECTAL: methohexitone; ANAESTHETIC TECHNנQUES: rectal; PHARMACOKINETICS: kinetics, methahoxitone.

From the Department of Anesthesia, University of Iowa College of Medicine, lowa City, Iowa.

Presented at the 1988 Canadian Anaesthetists' Society Annual Meeting, Halifax, N.S.

Address correspondence to: Dr. R. B. Forbes, Department of Anesthesia, University of lowa College of Medjcine, Iowa City, Iowa 52242 U.S.A.
The rectal administration of methohexitone to young children results in a safe, pleasant induction of anaesthesia $^{1-3}$ that may avoid problems encountered when paediatric patients are faced with parental separation, venipuncture or inhalational induction of anaesthesia prior to surgery. ${ }^{4-9}$ Although studies evaluating the use of one per cent, ${ }^{10}$ two per cent ${ }^{11}$ and ten per cent $^{2,3,12-14}$ rectal methohexitone have identified significant differences in the pharmacokinetics of different methohexitone solutions, information that correlates both plasma methohexitone concentration and the clinical effect associated with the use of various doses of methohexitone has not been reported. Therefore, the purpose of this study was to compare the pharmacokinetics and clinical effectiveness of four different doses of two per cent rectal methohexitone.

\section{Methods}

Sixty ASA physical status I or II children, less than six years of age and scheduled for elective surgery, were studied after obtaining informed written parental consent. All patients were unpremedicated and accompanied to the preoperative holding area by their parents. Each child was randomly assigned to receive $15 \mathrm{mg} \cdot \mathrm{kg}^{-1}, 20 \mathrm{mg} \cdot \mathrm{kg}^{-1}$, $25 \mathrm{mg} \cdot \mathrm{kg}^{-1}$ or $30 \mathrm{mg} \cdot \mathrm{kg}^{-1}$ rectal methohexitone.

Methohexitone was prepared by dissolving $500 \mathrm{mg}$ sodium methohexitone in $25 \mathrm{ml}$ of sterile water to form a two per cent solution which was instilled through a soft, plastic catheter inserted approximately $3 \mathrm{~cm}$ into the rectum. Parents remained with their children and comforted them until the child was asleep. The time from administration of the drug until the onset of sleep was determined by a blinded observer. For purposes of this investigation sleep was defined as loss of consciousness, unresponsiveness to verbal stimuli, and absence of voluntary movement when unstimulated. Each child was allowed up to fifteen minutes to fall asleep, then all children were transported to the operating room and anacsthesia was continued with nitrous oxide and halothane in oxygen.

Blood samples (1-2 $\mathrm{ml}$ ) for determination of methohexitone concentration in plasma were collected from a 
peripheral vein at $15,30,45$ and 120 minutes following administration of the rectal methohexitone. The samples were centrifuged and the plasma frozen for later assay using gas chromatography. Methohexitone concentrations were determined using the technique described by Van Hamme and Ghoneim. ${ }^{15}$ After extraction of methohexitone from the plasma samples with hexane, hexobarbitone was added as an internal control and separation of the sample was performed on a Hewlett Packard 5830A gas chromatograph. The area of the curves was measured on a Hewlett Packard integrator and methohexitone concentrations calculated from a calibration graph derived from control plasma to which known amounts of drug were added. Using this method of extraction the correlation coefficient of control plasma containing known amounts of methohexitone was linear for concentrations between $0.1-20 \mu \mathrm{g} \cdot \mathrm{ml}^{-1}(\mathrm{r}=0.99)$. Sensitivity of the assay was $0.03 \mu \mathrm{g} \cdot \mathrm{ml}^{-1}$ and reproducibility of duplicate samples \pm 8 per cent.

One-way analysis of variance was used to detect differences in the ages and weights of children among the four groups. The proportion of failed inductions was compared using Fisher's exact test (one-tailed). Regression analysis was performed to estimate the decrease in sleep induction time that accompanied an increase in methohexitone dose. Multivariate repeated measures analysis of variance was used to compare plasma methohexitone concentrations at four different times following drug administration. Because multiple comparisons were made the Bonferroni adjustment was used to protect the overall error rate. Statistical significance was accepted at $\mathrm{P}<0.05$. All values are expressed as mean $\pm \mathrm{SEM}$.

\section{Results}

The four groups of children were comparable in age and weight (Table I). Following rectal administration of methohexitone 50 of 60 patients fell asleep within 15 minutes (Figure 1). Four of the patients that did not fall asleep received $15 \mathrm{mg} \cdot \mathrm{kg}^{-1}$ rectal methohexitone, four received $20 \mathrm{mg} \cdot \mathrm{kg}^{-1}$, one received $25 \mathrm{mg} \cdot \mathrm{kg}^{-1}$ and one received $30 \mathrm{mg} \cdot \mathrm{kg}^{-1}$ methohexitone. The speed of induction and the proportion of children that fell asleep were significantly greater in the higher dose groups (Table II). Time to the onset of sleep was $9.2 \pm 0.7$ minutes, $8.6 \pm 0.9$ minutes, $7.5 \pm 0.5$ minutes and $7.1 \pm 0.6$ minutes for the $15 \mathrm{mg} \cdot \mathrm{kg}^{-1}, 20 \mathrm{mg} \cdot \mathrm{kg}^{-1}, 25 \mathrm{mg} \cdot \mathrm{kg}^{-1}$ and $30 \mathrm{mg} \cdot \mathrm{kg}^{-1}$ methohexitone groups, respectively. Regression analysis demonstrated a significant linear relationship between the dose administered and the time to the onset of sleep. From the regression analysis each 5 $\mathrm{mg} \cdot \mathrm{kg}^{-1}$ increase in methohexitone dose would be expected to result in a decrease in the time to the onset of
TABLE I Demographic data

\begin{tabular}{llll}
\hline Group & H & Age (months) & Weight (kg) \\
\hline $15 \mathrm{mg} \cdot \mathrm{kg}^{-1}$ & 15 & $42 \pm 3$ & $15.4 \pm 0.8$ \\
$20 \mathrm{mg} \cdot \mathrm{kg}^{-1}$ & 15 & $29 \pm 4$ & $12.5 \pm 0.6$ \\
$25 \mathrm{mg} \cdot \mathrm{kg}^{-1}$ & 15 & $40 \pm 3$ & $15.4 \pm 0.7$ \\
$30 \mathrm{mg} \cdot \mathrm{kg}^{-1}$ & 15 & $40 \pm 6$ & $14.7 \pm 1.2$ \\
\hline
\end{tabular}

Mean \pm SEM

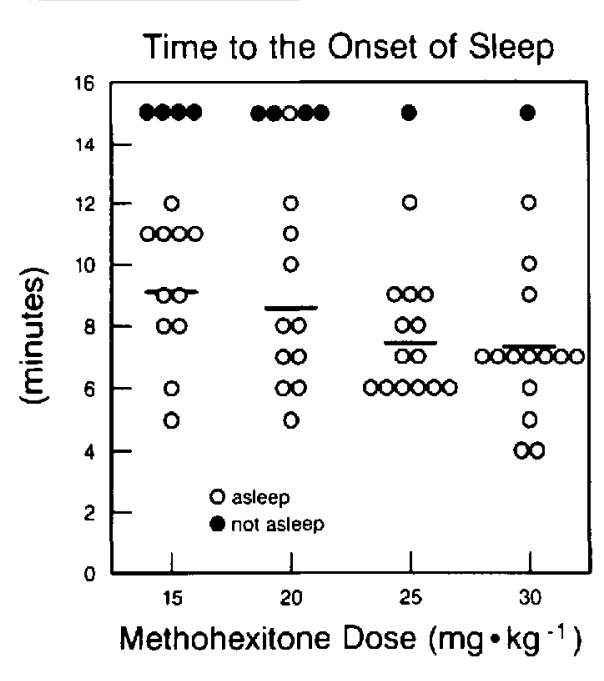

FIGURE 1 Time to the onset of sleep following rectal administration of methohexitone $15 \mathrm{mg} \cdot \mathrm{kg}^{-1}, 20 \mathrm{mg} \cdot \mathrm{kg}^{-1}, 25 \mathrm{mg} \cdot \mathrm{kg}^{-1}$ or $30 \mathrm{mg} \cdot \mathrm{kg}^{-1}$. Circles represent individual patients. $(-)$ indicates mean induction time.

sleep of 45 seconds with a 95 per cent confidence interval of 12 to 90 seconds.

Plasma methohexitone concentrations were significantly higher following administration of $30 \mathrm{mg} \cdot \mathrm{kg}^{-1}$ at all time periods when compared with the $15 \mathrm{mg} \cdot \mathrm{kg}^{-1}$ group and also higher than the plasma concentrations achieved 15,30 and 45 minutes after administration of $20 \mathrm{mg} \cdot \mathrm{kg}^{-1}$ rectal methohexitone (Figure 2).

For six of the ten patients that did not fall asleep within 15 minutes the initial plasma samples were delayed for up to 30 minutes following administration of rectal methohexitone. The mean plasma methohexitone concentration in the ten patients that did not fall asleep within fifteen minutes was $1.09 \pm 0.3 \mu \mathrm{g} \cdot \mathrm{ml}^{-1}$ (range $0.53-2.58$ $\mu \mathrm{g} \cdot \mathrm{ml}^{-1}$ ) immediately following the induction of anaesthesia with halothane and nitrous oxide. 
TABLE II Induction data

\begin{tabular}{lll}
\hline $\begin{array}{l}\text { Rectal } \\
\text { melhohexilone }\end{array}$ & $\begin{array}{l}\text { Dose } \\
15-20 \mathrm{mg} \cdot \mathrm{kg}^{-1}\end{array}$ & $\begin{array}{l}\text { Dose } \\
25-30 \mathrm{mg} \cdot \mathrm{kg}^{-1}\end{array}$ \\
\hline $\begin{array}{l}\text { Incidence of } \\
\text { failed lnductions }(\%)\end{array}$ & $8 / 30(27 \%)$ & $2 / 30(7 \%)^{*}$ \\
\hline
\end{tabular}

*Fisher exaci test $P<0.05$.

\section{Plasma Methohexitone Concentration}

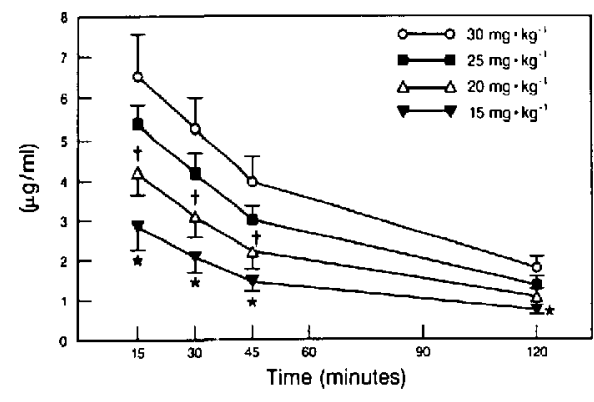

FGURE 2 Plasma methohexitone concentrations following rectal administration of methohexitone $15 \mathrm{mg} \cdot \mathrm{kg}^{-1}, 20 \mathrm{mg} \cdot \mathrm{kg}^{-1}$, $25 \mathrm{mg} \cdot \mathrm{kg}^{-1}$ or $30 \mathrm{mg} \cdot \mathrm{kg}^{-1}$. Mean \pm SEM. ${ }^{*} \mathrm{P}<0.0515 \mathrm{mg} \cdot \mathrm{kg}^{-1}$ versus $30 \mathrm{mg} \cdot \mathrm{kg}^{-1} ; \nmid P<0.0520 \mathrm{mg} \cdot \mathrm{kg}^{-1}$ versus $30 \mathrm{mg} \cdot \mathrm{kg}^{-1}$.

Soiling occurred in two children following administration of rectal methohexitone and one of these children failed to fall asleep. In addition, one child became apnoeic following the onset of sleep. No other side effects or postoperative complications were encountered.

\section{Discussion}

Rectal administration of two per cent methohexitone to healthy paediatric patients in doses of $15-30 \mathrm{mg} \cdot \mathrm{kg}^{-1}$ is an effective technique for providing basal narcosis before surgery. Despite having received no preoperative sedation, 83 per cent of the children were asleep within 15 minutes. Of the ten patients that did not fall asleep, nine were sedate and separated easily from their parents for a subsequent inhalational induction of anaesthesia. A single patient, who received $25 \mathrm{mg} \cdot \mathrm{kg}^{-1}$ two per cent methohexitone, remained alert and became uncooperative during induction with nitrous oxide, oxygen and halothane. Although all four doses of rectal methohexitone provided adequate basal narcosis, sleep was achieved more rapidly and more consistently when larger doses of methohexitone were administered.

In a previous investigation using ten per cent metho- hexitone Lui et al. also found a significant decrease in the time to the onset of sleep, as the dose of methohexitone was increased from $20 \mathrm{mg} \cdot \mathrm{kg}^{-1}$ to $30 \mathrm{mg} \cdot \mathrm{kg}^{-1}$; but, in contrast to this study the number of failed inductions was unchanged with increasing methohexitone dose. ${ }^{13}$ Laishley et al., however, found no significant difference in the time to the onset of sleep between two groups of patients that received either $15 \mathrm{mg} \cdot \mathrm{kg}^{-1}$ or $25 \mathrm{mg} \cdot \mathrm{kg}^{-1}$ ten per cent methohexitone; but the incidence of failed inductions was significantly higher in the children that received 15 $\mathrm{mg} \cdot \mathrm{kg}^{-1}$ methohexitone. Laishley et al. also found that use of $15 \mathrm{mg} \cdot \mathrm{kg}^{-1}$ ten per cent methohexitone resulted in a higher incidence of failed inductions than occurred with $15 \mathrm{mg} \cdot \mathrm{kg}^{-1}$ of a one per cent solution. He concluded that $15 \mathrm{mg} \cdot \mathrm{kg}^{-1}$ one per cent rectal methohexitone was as effective as $25 \mathrm{mg} \cdot \mathrm{kg}^{-1}$ of a ten per cent solution for the induction of anaesthesia in paediatric patients. ${ }^{10}$

In contrast to Laishley's study we found that the incidence of failed inductions was significantly higher among the children that received $15-20 \mathrm{mg} \cdot \mathrm{kg}^{-1}$ two per cent rectal methohexitone when compared to children that received $25-30 \mathrm{mg} \cdot \mathrm{kg}^{-1}$. A number of factors may have contributed to this difference. In a study comparing different concentrations of methohexitone solution Forbes and Vandewalker measured plasma methohexitone levels following rectal administration of methohexitone as either a two per cent or ten per cent solution and found that plasma methohexitone levels were significantly higher following administration of two per cent methohexitone. " Although plasma concentrations have not been determined following the use of one per cent methohexitone, higher plasma levels may be achieved with the one per cent preparation, resulting in the improved efficacy of the lower doses of methohexitone seen in Laishley's study. Also, Laishley et al. allowed children up to 20 minutes to fall asleep. In this study patients not asleep within 15 minutes following administration of methohexitone underwent inbalational induction of anaesthesia. In the children who did not fall asleep the mean plasma methohexitone concentration was $0.88 \pm 0.13 \mu \mathrm{g} \cdot \mathrm{ml}^{-1}$ $(n=4) 15$ minutes after drug administration and $1.58 \pm$ $0.46 \mu \mathrm{g} \cdot \mathrm{ml}^{-1}(\mathrm{n}=10)$ at 30 minutes. In some patients the plasma methohexitone concentration continued to increase for at least 30 minutes after administration of the drug. These children, therefore, may have required a longer period of time to fall asleep than was allowed in this study.

Other factors that may affect the absorption and bioavailability of rectally administered medications ${ }^{16,17}$ include the depth of catheter insertion, the site of drug absorption from within the rectum, and the diversion of methohexitone into the portal circulation where first-pass 
hepatic elimination (hepatic extraction ratio 0.5$)^{18}$ substantially reduces bioavailability. In addition, the body position of the patient, the presence of faeces in the rectum, and the operating room environment in which the technique is used may affect the incidence of failed inductions. However, the influence of these factors on induction has not been evaluated.

There was no significant difference in the incidence of complications among the four dose groups. Soiling occurred in 3.3 per cent of the patients, which is similar to the incidence of soiling reported by other investigators. ${ }^{3,4,11-14}$ It has been suggested that the use of a larger volume of a dilute methohexitone solution will initiate the defecation reflex, resulting in more frequent soiling. ${ }^{19.20}$ This was not evident in our study, as soiling occurred in only two patients both of whom were in the group that received the smallest volume of methohexitone. A single patient became apnoeic during the introduction of $\mathrm{N}_{2} \mathrm{O}$ and halothane. This child had received 30 $\mathrm{mg} \cdot \mathrm{kg}^{-1}$ methohexitone and required manual support of the airway and positive pressure ventilation.

In conclusion, we found that rectal administration of two per cent methohexitone, $15-30 \mathrm{mg} \cdot \mathrm{kg}^{-1}$, was effective for providing basal narcosis in children. Increasing the dose of methohexitone resulted in a more rapid and reliable onset of sleep without increasing the incidence of complications. However, increasing the induction dose also resulted in significantly higher plasma methohexitone concentrations two hours following drug administra. tion. Therefore, the use of a standard induction dose of rectal methohexitone for all patients is inappropriate. The use of larger doses of rectal methohexitone may be required in anxious children having longer surgical procedures in whom a more rapid onset of sleep is desired. However, we recommend that the clinical circumstances be carefully considered and that the dose of rectal methohexitone administered be individualized to meet the specific anaesthetic requirements of each child.

\section{Acknowledgements}

The authors gratefully acknowledge Dr. C. K. Chiang, Motomi Mori and Sara Paul for their assistance in the completion of the investigation and preparation of the manuscript.

\section{References}

1 Orallo $M O$, Eather $K F$. Sodium methohexital as a rectal agent in pediatric anesthesia: a controlled comparison with sodjum thiamylal. Anesth Analg 1965; 44: 97-103.

2 Budd DC, Dornette WHL, Wright JF. Methohexital for rectal basal narcosis. Anesth Analg 1965; 44: 222-5.
3 Goresky GV, Steward DS. Rectal methohexitone for induction of anaesthesia in children. Can Anaesth Soc J 1979; 26: 213-5.

4 Eckenhoff JE. Relationship of anesthesia to postoperative personality changes in children. Am J Dis Child 1953; 86: 587-91.

5 Lee JS, Green NM. Parcntal presence and emotional state of children prior to surgery. Clinical Pediatrics 1969;8: 126-30.

6 Hannallah $R S$, Rosales $J K$. Experience with parents' presence during anaesthesia induction in children. Can Anaesth Soc J 1983; 30: 286-9.

7 Bothe A, Galdston R. The child's loss of consciousness: a psychiatric view of pediatric anesthesia. Pediatrics 1972; 50: 252-63.

8 Hodges $R J H$. Induction of anaesthesia in young children. Lancet 1960; $1: 82-7$

9 Meyers EF, Muravchick $S$. Anesthesia induction technics in pediatric paticnts: a controlled study of behavioral consequences. Anesth Analg 1977; 56: 538-42.

10 Laishley $R S$, O'Caliaghan $A C$, Lerman J. Effects of dose and concentration of rectal methohexitone for induction of anaesthesia in children. Can Anaesth Soc J 1986; 33: 427-32.

11 Forbes $R B$, Vandewalker $G E$. Comparison of two and ten per cent rectal methohexitone for induction of anaesthesia in children. Can J Anuesth 1988; 35: 345-9.

12 Quaynor H, Corbey $M$, Björkman $S$. Rectal induction of anaesthesia in children with methohexitone. $\mathrm{Br} J$ Anaesth 1985; 57: 573-7.

13 Liu LMP, Coudsouzian NG, Liu PL. Rectal methohexital premedication in children, a dose-comparison study. Anesthesiology 1980; 53: 343-5.

14 Liu LMP, Gaudreault P, Friedman PA, Goudsouzian NG, Liu $P L$. Methohexital plasma concentrations in children following rectal administration. Anesthesiology 1985; 62: $567-70$.

15 Van Hamme $M J$, Ghoneim MM. A sensitive gas chromatograph assay for thiopentone in plasma. $\mathrm{Br} \mathrm{J}$ Anaesth 1978; 50: 143-5.

16 De Boer AG, Moolenaar F, de Leede LGJ, Breimer $D D$. Rectal drug administration: clinical pharmacokinetic considerations. Clin Pharmacokinet 1982; 7: 285311.

17 De Boer $A G$, de Leede $L G J$, Breimer $D D$. Drug absorption by the sublingual and rectal routes. Br J Anaesth 1984; 56: 69-82.

18 Rowland $M$. Influence of route of administration on drug availability. J Pharm Sci 1972; 61: 70-4.

19 Gregory GA. Pediatric Anesthesia. New York: Churchill Livingstone, 1983, p. 444.

20 Berry FA. General physiology of patient preparation, 
premedication, and induction of anesthesia; and inhala tion ancsthetic agents. In: Anesthetic Management of Difficult and Routine Pediatric Patients. Berry FA (Ed). New York: Churchill Livingstone, 1986, p. 31

\section{Résumé}

Suite a l'administration inera-rectale de 15, 20, 25 et 30 $m g \cdot \mathrm{kg}^{-1}$ de méthohexital à deux pour cent, nous en avons mesuré les taux sériques chez 60 enfants de un d̀ six ans. Nous avons prélevé les échantillons veineux à $15,30,45$ et 120 minutes post-administration et un tiers indépendant chronométrait l'intervalle d'action jusqu' à l'apparition de somnolence. Chez cinquante des enfants, cet intervalle était inférieur à 15 minutes alors qu' au même moment, neuf des dix autres étaien assez calmes pour qu'on les sépare de leurs parents et qu'on procède à une induction par inhalation. L'intervalle d'action s'est avéré inversement proportionnel à la dose de méthohexital utilisée et la somnolence atteinte plus efficacement à des doses de 25 et de $30 \mathrm{mg} \cdot \mathrm{kg}^{-t}$. De plus, d 120 minutes, les taux sériques avec une dose de $30 \mathrm{mg} \cdot \mathrm{kg}^{-1}$ étaient supérieurs à ceur atteints avec 15 ou $20 \mathrm{mg} \cdot \mathrm{kg}^{-1}$. La dose n' a pas eu d' influence sur l' incidence de complication. Nous croyons que le jugement clinique doit présider à l'individualisation des doses appropriées aux besoins anesthésiques de chaque enfant. 